\title{
LETTER
}

\section{"It was a nightmare until I saw my wife": the importance of family presence for patients with COVID-19 hospitalized in the ICU}

\author{
Nancy Kentish-Barnes ${ }^{1 *}$ (D) Philonille Degos ${ }^{1}$, Clémence Viau ${ }^{1}$, Frédéric Pochard ${ }^{1,2}$ and Elie Azoulay ${ }^{1}$
}

(C) 2021 Springer-Verlag GmbH Germany, part of Springer Nature

Dear Editor,

During the initial pandemic of coronavirus disease 2019 (COVID-19), visits in the intensive care unit (ICU) were either banned or highly restricted. Consequently, family members and patients were often separated from each other. Quantitative and qualitative research has shown that this restriction was an extremely difficult and even harmful experience for both family members and ICU clinicians $[1,2]$. Lack of visits is a well-known risk factor for delirium [3] and studies have shown that extending visiting policies can strongly reduce both the incidence of delirium and its length [4]. In this qualitative pilot study that included semi-structured interviews with 12 ICU survivors of the COVID-19 9-10 months after their discharge, we sought to better understand the experience of patients' hospitalization in the ICU during the first wave of the pandemic (Supplemental material). Qualitative analysis provides an in-depth insight into the relationship between the patient and his loved-one in the ICU, although our data may not precisely translate how patients actually felt in the moment, given a potential for recall bias and the effect of media exposure between the ICU stay and the interviews.

Most patients (9/12) reported having no memories of their ICU admission: their first memory was gaining consciousness after their coma (due to sedation for mechanical ventilation). Patients described being agitated and confused, not knowing whether their dreams were reality

\footnotetext{
*Correspondence: nancy.kentish@aphp.fr

${ }^{1}$ Famiréa Research Group, Service de Médecine Intensive Et Réanimation, Hôpital Saint Louis, AP-HP, Groupe Hospitalo-Universitaire AP-HP Nord, Paris, France

Full author information is available at the end of the article
}

or not (Table 1, Q1). Many patients described terrifying dreams during which they thought they were going to die (Table 1, Q2). ICU delirium is well described and can cause patients to have horrifying, violent hallucinations to the point where they feel that they are going crazy. In our study, patients described not knowing where they were and having no familiar faces to reassure them (Table 1, Q3).

Once fully awake, patients discovered that they needed to re-learn how to walk, how to talk and how to eat (Table 1, Q4). Patients felt scared, lost, alone, and had no safe landmarks. The one event that brought them back to a reality with a real meaning was the presence of their loved-one (Table 1, Q5 and 6). Patients with no visits felt that if they had benefited from the visit of a family member it would also have given them courage and energy to fight harder to leave the ICU as soon as possible, possibly reducing their length of stay (Table 1, Q7 and Q8). Any contact or event related to their family increased their wellbeing (Table 1, Q9). The emotional distress of waking up after such an experience was overwhelming and patients needed the help of their loved-ones to get through it. Family members are not simple visitors: they play active roles in the ICU and can help the patients by not only reassuring, comforting and guiding them but also by helping them integrate the ICU experience as part of their broader life story: meaning making is an essential part of getting better. Moreover, the absence or distance of their loved-ones increased their stress (Table 1, Q10) and their concern that something terrible may have happened to them (Table 1, Q11).

Banning families from the ICU is deleterious at all times and specifically during the pandemic during which patients can spend weeks in a coma, thus increasing the

\section{Springer}


Table 1 Illustrative quotes

Quotes

Patients' characteristics

\section{Waking-up in the ICU alone, between nightmare and reality}

Quote 1

It was curious experience. It was actually insane. I didn't know where the line was between my real life and what I was going through. I felt like it wasn't me and that I was looking at the scene from the outside. Finally I told myself that dying wouldn't be so terrible after all

Quote 2

I had a lot of dreams that for me were real but weren't actually real — but I didn't know that. I was suffocating calling for help and no one would come, and I would die every time

Quote 3 When I woke up I discovered that I wasn't at home so it
just wasn't right, I was far from everything, far from my
loved ones, I didn't recognize anything or anybody and I
thought to myself "what am I doing here?"
Male patient, aged 73, 10 weeks in ICU, including 9 under seda- tion for MV
Male patient, aged 65, 6 weeks in ICU, including 5 under sedation for MV ICU 1

Female patient, aged 68, 3 weeks in ICU, including 2 under sedation for MV

ICU 3

Male patient, aged 74, 31/2 weeks in ICU, including 2 under sedation for MV

ICU 1

\section{Meaning-making and the possibility of family implication}

Quote 5 It was a mixture of nightmare and reality. I thought I had been kidnapped and I wanted to escape. I was afraid; I didn't understand anything (...). It was horrible, a nightmare, until I saw my wife, she was the one who allowed me to reconnect with reality. It was one visit but it was exceptional. It was she who helped me understand (...) because everything was blurred. After her visit, I began to recognize the caregivers around me and to understand where I was

\begin{tabular}{|c|c|c|}
\hline Quote 6 & $\begin{array}{l}\text { I was completely out of sync; I didn't know what time it was, } \\
\text { what day it was, if it was day or night, so in fact when I } \\
\text { saw her (wife) it was joy, I realized that all was not lost. It } \\
\text { was hard not to see my children right away, but at least I } \\
\text { saw my wife. If I hadn't seen her it would have been much } \\
\text { harder }\end{array}$ & $\begin{array}{l}\text { Male patient, aged } 41,2 \text { weeks in ICU, including } 10 \text { days under } \\
\text { sedation for MV } \\
\text { ICU } 4\end{array}$ \\
\hline Quote 7 & $\begin{array}{l}\text { I would have liked to have at least one visit from my wife, } \\
\text { even behind the windows... I would have been more } \\
\text { courageous. It would have given me more hope, it would } \\
\text { have made me want to make more effort, to fight even } \\
\text { more... }\end{array}$ & $\begin{array}{l}\text { Male patient, aged } 70,71 \frac{1}{2} \text { weeks in } I C U \text {, including } 6 \text { under seda- } \\
\text { tion for MV } \\
\text { ICU } 6\end{array}$ \\
\hline Quote 8 & Once you see your family, you see the future & $\begin{array}{l}\text { Male patient, aged } 58,4 \text { weeks in ICU, including } 2 \text { under sedation } \\
\text { for MV } \\
\text { ICU2 }\end{array}$ \\
\hline Quote 9 & $\begin{array}{l}\text { The most important moment for me was the shower I took } \\
\text { in the ICU at my wife's request- the fact that she was the } \\
\text { one who asked for it was... everything about my wife is } \\
\text { just divine, it's paradise. During the shower, I told myself } \\
\text { that life is beautiful, I felt alive for the first time since I } \\
\text { woke up }\end{array}$ & $\begin{array}{l}\text { Male patient, aged 70, } 2 \text { weeks in ICU, } 10 \text { days under sedation } \\
\text { for MV } \\
\text { ICU } 3\end{array}$ \\
\hline \multicolumn{3}{|c|}{ Family absence as a stress } \\
\hline Quote 10 & $\begin{array}{l}\text { I felt that it was serious because you couldn't see anyone, } \\
\text { my family wasn't there and that was very stressful. I felt } \\
\text { very isolated. I saw my wife once behind a glass win- } \\
\text { dow... I think that all those protective barriers caused me } \\
\text { a lot of stress }\end{array}$ & $\begin{array}{l}\text { Male patient, aged } 73,5 \text { weeks in ICU, including approximately } 4 \\
\text { weeks under sedation for MV } \\
\text { ICU } 3\end{array}$ \\
\hline Quote 11 & $\begin{array}{l}\text { As I couldn't see my wife, I was worried that something had } \\
\text { happened to her and they didn't want to tell me }\end{array}$ & $\begin{array}{l}\text { Male patient, aged } 69,2 \text { weeks in ICU, } 11 \text { days under sedation } \\
\text { for MV } \\
\text { ICU } 5\end{array}$ \\
\hline
\end{tabular}

\footnotetext{
${ }^{a} M V$ mechanical ventilation
}

Male patient, aged 50, 4 weeks in ICU, including 3 under sedation for MV

ICU 2$$
(\mathrm{Cu})
$$ 
risk of delirium and vulnerability. While adapting visiting policies was undoubtedly necessary given the nature of the threat, our pilot study shows that patients suffered considerably from the absence of their loved-ones. Those who did benefit from a visit were able to feel safer and to give meaning to their hospitalization more rapidly. To avoid traumatic experiences [5], specific patient- and family-centered guidelines for crisis management are urgently needed that include the possibility of regular family visits.

\section{Supplementary Information}

The online version contains supplementary material available at https://doi. org/10.1007/s00134-021-06411-4.

\section{Author details}

${ }^{1}$ Famiréa Research Group, Service de Médecine Intensive Et Réanimation, Hôpital Saint Louis, AP-HP, Groupe Hospitalo-Universitaire AP-HP Nord, Paris, France. ${ }^{2}$ DMU Neurosciences, Département de Psychiatrie Et de Médecine Addictologique, Hôpital Fernand Widal, AP-HP, Groupe Hospitalo-Universitaire AP-HP Nord, Paris, France.

\section{Acknowledgements}

The study was approved by the research ethics board Sud Méditerranée (2020-A00809-30; CNRIPH: 20.03.27.73019).

\section{Author contributions}

NKB and EA wrote the study protocol; PD and CV did the interviews; NKB, PD $C V$, and FP analyzed the data and wrote the manuscript; NKB, PD, CV, FP, and EA revised the manuscript.

\section{Funding}

Study funded by the French Ministry of Health, PHRC 2020, APHP200389.

\section{Declarations}

\section{Conflicts of interest}

NKB, PD, CV and FP have no conflicts of interest to declare. EA has received fees for lectures from Gilead, Pfizer, Baxter, and Alexion, unrelated to the present work. His research group has been supported by Ablynx, Fisher and Payckle, Jazz Pharma, and MSD, outside the submitted work.

\section{Publisher's Note}

Springer Nature remains neutral with regard to jurisdictional claims in published maps and institutional affiliations.

Received: 1 March 2021 Accepted: 9 April 2021

Published online: 11 May 2021

\section{References}

1. Ely EW (2021) Each person is a world in COVID-19. Lancet Respir Med 9(3):236-237

2. Kentish-Barnes N, Morin L, Cohen-Solal Z, Cariou A, Demoule A, Azoulay E (2021) The lived experience of ICU clinicians during the coronavirus disease 2019 outbreak: a qualitative study. Crit Care Med. https://doi.org/ 10.1097/CCM.0000000000004939

3. Van Rompaey B, Elseviers MM, Schuurmans MJ et al (2009) Risk factors for delirium in intensive care patients: a prospective cohort study. Crit Care 13:R77

4. Pun B, Badenes R, Heras La Calle G et al (2021) Prevalence and risk factors for delirium in critically ill patients with COVID-19 (COVID-D): a multicentre cohort study. Lancet Respir Med. https://doi.org/10.1016/S22132600(20)30552-X

5. Estella Á (2020) Compassionate communication and end-of-life care for critically ill patients with SARS-CoV-2 infection. J Clin Ethics 31(2):191-193 